\title{
Towards a Best Use of National Knowledge Network for the Knowledge Sharing
}

\author{
Pranav Kumar Singh \\ Assistant Professor \\ Department of CSE \\ CIT Kokrajhar, BTAD \\ Assam, India
}

\author{
Ranjan Maity \\ Assistant Professor \\ Department of CSE \\ CIT Kokrajhar, BTAD \\ Assam, India
}

\author{
Tania Sarkar \\ Assistant Professor \\ Department of CSE \\ CIT Kokrajhar, BTAD \\ Assam, India
}

\begin{abstract}
National Knowledge Network (NKN) is a project of Government of India, which will connect Educational Institutes, R\&D institutions, Health service facilities, Agricultural institutions, Libraries of India and a future plan of collaboration with the International research organizations. This paper presents detail proposed Network Infrastructure and Application framework setup that an Institute need to have for the best use of NKN. It also describes the services and other features of the NKN. Critical security issues have been identified and a model is proposed which can be implemented by the Institutes for securing such high speed networks.
\end{abstract}

\section{General Terms}

National Knowledge Network, Knowledge Sharing, Proposed Solution

\section{Keywords}

NKN, Network Architecture, Security, Services, Application framework

\section{INTRODUCTION}

The main objectives of all the Institutes are to impart education in their offering courses, interdisciplinary courses, to conduct research in the relevant fields, and also to do further innovation and planning for advancement of learning and dissemination of knowledge. ICT plays a very important role for the knowledge sharing and research activities. National Knowledge Network (NKN) [1] is a high speed network which aims to connect all the higher educational institutes, universities and research organizations so that they can work together, share the knowledge resources and can do the collaborative research work. NKN is bridging the gap between the various research organization \& education Institutes and also facilitating advanced distance education in India. The National Informatics Centre (NIC) is the implementing unit of the NKN.

For the best use of NKN i.e. easy access of knowledge, better knowledge services and dissemination of knowledge, all the Institutes need to have their own scalable campus wide local area network, set of servers, network security components, and set of applications.

NKN network design and architecture, which is based on distributed networking approach is shown in fig1..NKN comprises 3 Layer of distribution: Core, distribution Layer in different states of the country and Edge Distribution connecting to various Institutes and research organizations. Detail of the architecture is given in section 2.1 of this paper.

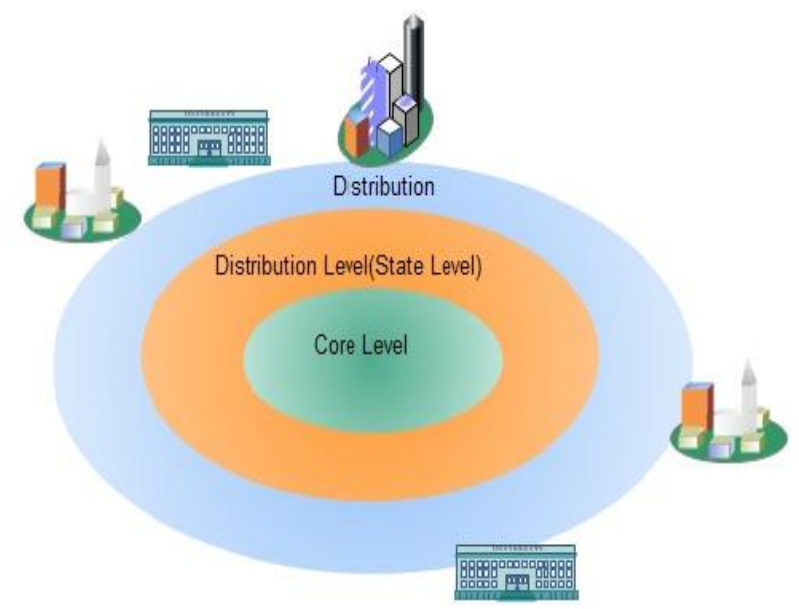

Fig1. NKN Design and Architecture [2]

The paper is organised as follows. Section 2 reports the state of art of National Knowledge Network that includes its Infrastructure, Services, and Future Plan. Section 3 briefly describes Proposed Campus Network Architecture of the Institutes. Section 4 outlines the security measures needs to be taken by the Institutes. Section 5 describes proposed framework of Applications needs to be developed on top of NKN by the connected Institutes. Section 6 draws the main conclusions derived from this work.

\section{NKN (National Knowledge Network)}

The NKN is a state-of-the-art multi-gigabit pan-India network [1].NKN provides a unified high speed and low latency network backbone for all connected institutions in the country. NKN has provided a platform for scientists, researchers and students from different backgrounds and diverse geographical location so that they can work together for advancing research \& development in critical and emerging areas. NKN has already driven the research activities across the country. Most of the Institutes connected by NKN today are sharing their information and resources for innovation, invention and research work.

National Knowledge Commission [3] in its proposal to the Govt. of India has clearly stated that the main objective of NKN implementation is to build quality Institutions across the country by facilitating them with advance high speed, low latency network support. In future this network will connect districts, villages, gram panchayat, and primary education schools in remote area for their education, training and egovernance.

\subsection{NKN Architecture}

NKN network comprises 3 layer of distributed network Architecture as shown in figure2 [7]: 
1. Core (multiple of 10 Gbps support)

2. Distribution(multiple of $2.5 / 10 \mathrm{Gbps}$ )

3. Access (100 Mbps - 1 Gbps)

The backbone of the NKN network has connectivity to 7 fully meshed Supercore. The network is further distributed through 26 Core locations (distribution) partially meshed connectivity with Supercore locations. The distribution layer connects entire country to the core of the network using multiple links at speeds of 2.5/10 Gbps. The end users or connecting Institutions presently eight hundred twenty three are being connected upto a speed of 1 Gbps.

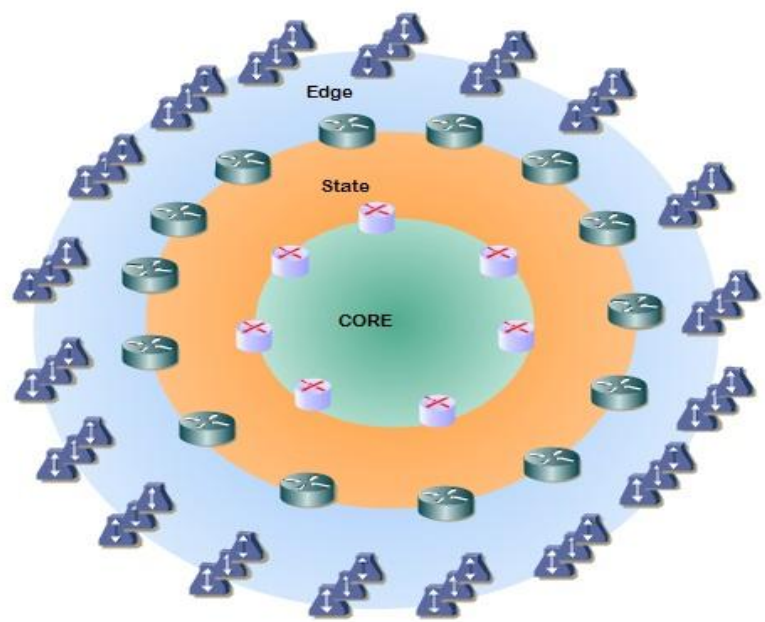

Fig2. Three Layer Routing Architecture of NKN [7]

\subsection{Services \& Applications}

NKN provides three main services [5] and these services are Generic Services, Community Services and Special Services.

Main service under Generic service is Internet, in addition to this NKN also helps connecting nodes to provide mail, messaging, DNS, Video portals and streaming etc. Under Community services NKN provides storage, grid computing, collaboration, authentication and applications. Special services provided by NKN mainly include VPN services at different layer and its stitching services.

NKN has recently launched following product \& services under generic services [6]: LDAP, PaaS, BitAmbulator, Open Source IP Registrar (OSIR), Bandwidth Monitoring Service, Mail \& Messaging Service, Smart Class Service, DNS service.

\subsubsection{Applications of NKN}

Main applications of NKN are [7]: Countrywide Virtual Classroom, Collaborative Research, Virtual Library, Sharing of Computing Resources, Grid Computing, Network Technology Test-bed, e-Governance and Cloud Computing.

\subsection{Future Plan}

Future plan of NKN is to have presence in more than 500 districts of India with connectivity to over 1500 Institutions / Organisations / Laboratories under various categories throughout the country [8].

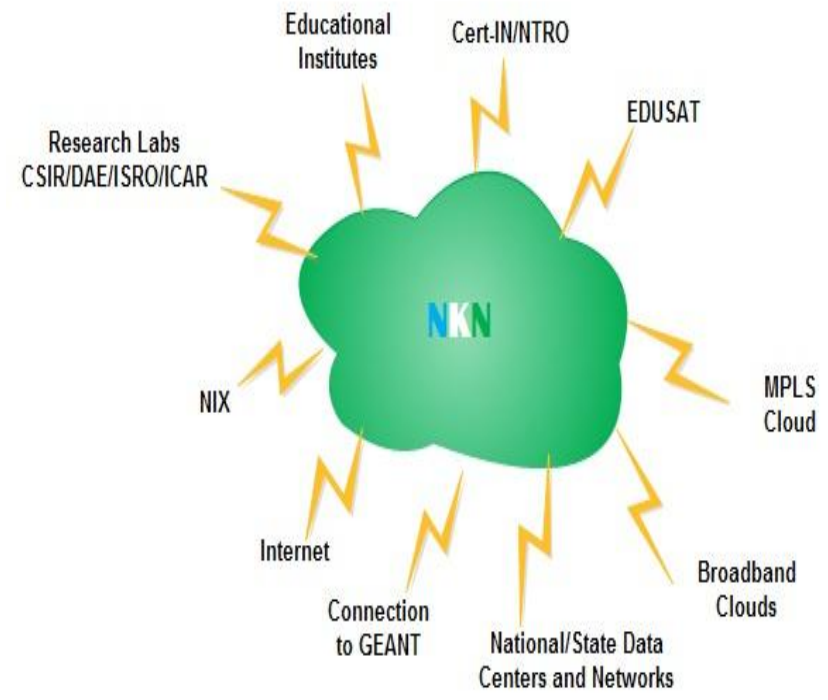

Fig3. NKN Connectivity Plan [8]

NKN provides national \& international connectivity to its users for collaborative research work few of those are mentioned below [9 to 14]:

i. BARC : Bhabha Atomic Research Centre India

ii. GARUDA: National Grid Computing initiative by CDAC, India,

iii. TEIN3(Trans Eurasia Information Network): The research and education network for Asia-Pacific, Linking AsiaPacific to Europe and beyond

iv. GLORIAD: Global Ring Network for Advanced Application Development

v. EU-India Grid: Global networks connecting Scientific Research Communities around the world. Networks such as GÉANT (The Pan-European Education and Research Network), TEIN3 (The Trans-Eurasia Information Network) and the NKN (National Knowledge Network of India).

vi. Connectivity to ESRF, Grenoble, France for Remote Physics Experiment 


\section{PROPOSED CAMPUS WIDE LAN ARCHITECTURE}

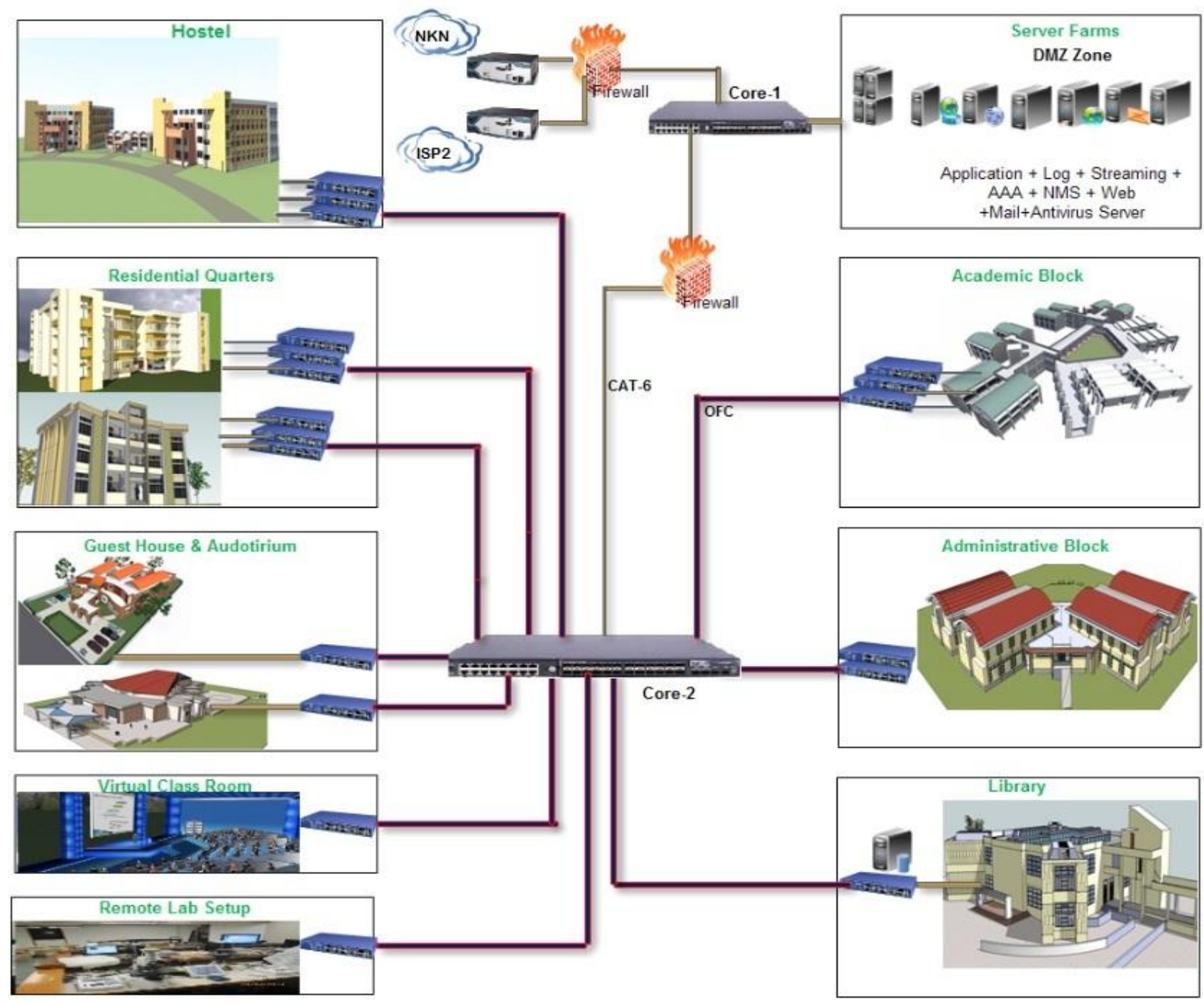

Fig4. Campus Wide LAN Architecture

Network Architecture is broadly categorized in four Zones 1. Internet: Internet is basically outside world or WAN connectivity (e.g. NKN and other ISPs)

2. DMZ (Demilitarized Zone): External Firewall, Here all the publicly accessible servers are placed within firewall policy of DMZ to make it highly secured zone

3. Internal Firewall, We have proposed additional firewall for securing the Local Servers from internal threats kept in Private LAN.

4. LAN:- Here all the departments are connected with the L2 Switches(Access) which in turn is connected to L3 Switch(Core) in VLAN. In this proposed architecture the detail specifications and configurations for the devices (Firewall + Servers + Switches L3 \& L2) are not given but we suggest that the devices must be purchased, configured and installed with proper planning and study so that it can be easily migrated to any possible future changes in network technology, topology, protocols, standards and other performance metrics. Firewall configuration must be done properly that includes Firewall Rules, NAT, Web filtering, Application filtering, Intrusion Prevention System, Gateway Anti-Virus and Anti-Spyware, Bandwidth Management, VPN, and Anti Spam etc.

As suggested by Prof. H. Krishnamurthy, Chief Research Scientist, IISc Bangalore in [8] that while designing a network $\&$ services we should always take care of five important metrics given as:-

1. Performance Scalability

2. Availability \& fault tolerance

3. Robust \& Maturity

4. Security \& Access Control

5. Performance Standard \& Interoperability. 


\section{PROPOSED APPLICATION FRAMEWORK}

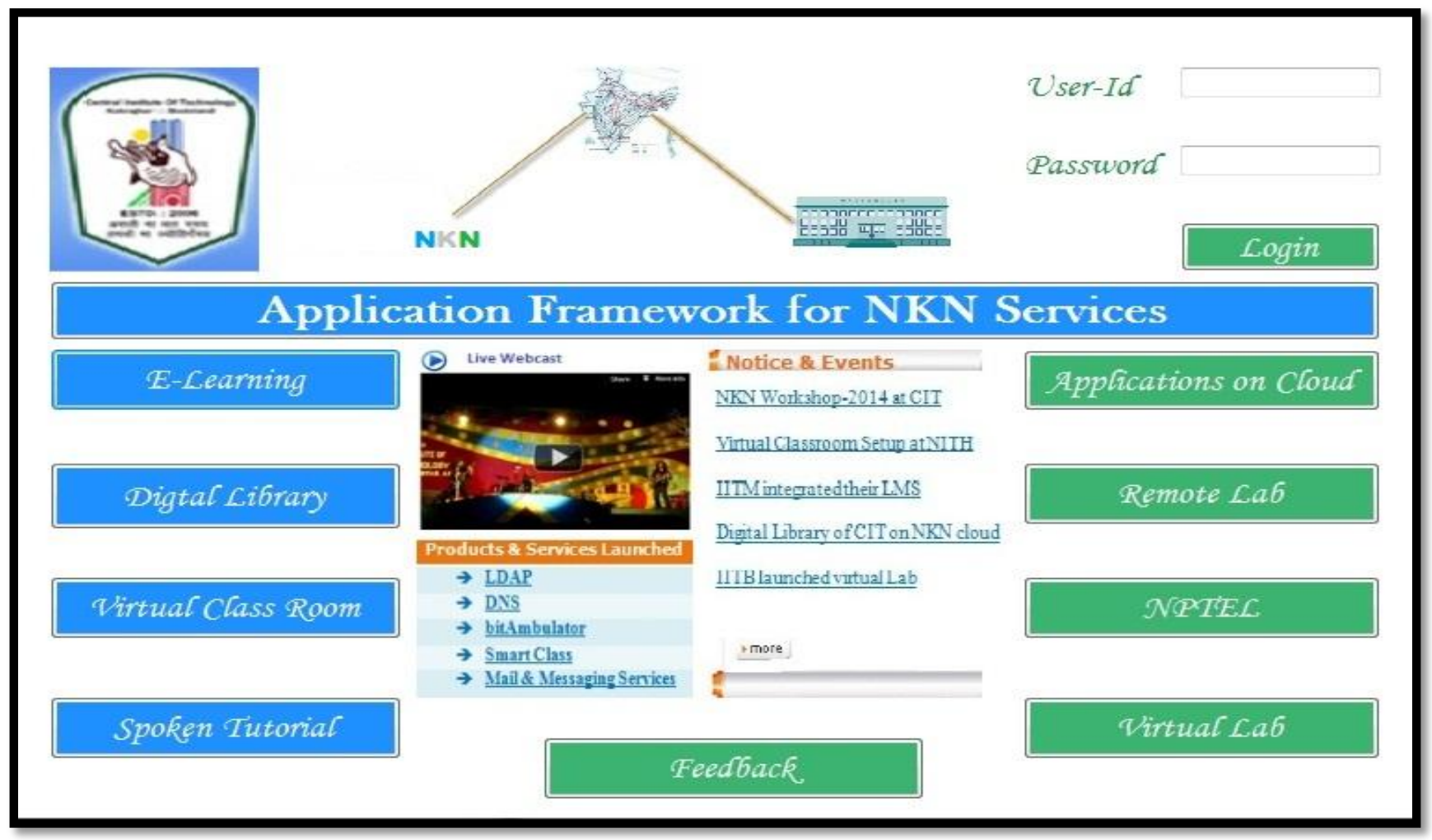

Fig5. Web based Application framework for NKN Services

\begin{tabular}{|c|c|c|}
\hline $\begin{array}{l}\text { User } \\
\text { Privileges }\end{array}$ & Services & User Action \& Characteristics \\
\hline $\begin{array}{l}\text { Teacher } \\
\& \text { Student }\end{array}$ & E-learning & $\begin{array}{l}\text { This module will help the Institutes to participate and use e-learning platform } \\
\text { developed by various institute and Universities such as their LMS on } \\
\text { MOODLE. Click event of E-learning will enable the users to see the list of } \\
\text { Institutes offering e-learning courses and its availability for the use. After } \\
\text { successful login User can select choice and can use this service if it is allowed } \\
\text { to that particular Institute from which the User belongs. }\end{array}$ \\
\hline $\begin{array}{l}\text { Teacher } \\
\text { \& Student }\end{array}$ & Digital Library & $\begin{array}{l}\text { Click event on digital Library will generate the list of Institutes connected to } \\
\text { NKN and who's digital libraries are available including list of books, } \\
\text { research papers, videos etc for various departments and subjects. IITB in } \\
\text { their e-foundry subjects has made available their digital library. } \\
\text { http://efoundry.itb.ac.in/Academy/index.jsp }\end{array}$ \\
\hline $\begin{array}{l}\text { Teacher \& } \\
\text { Nodal officer }\end{array}$ & Virtual Class Room & $\begin{array}{l}\text { Click event on Virtual Classes will generate the list of Institutes connected to } \\
\text { NKN and whose Virtual Classes are available with their Schedules and other } \\
\text { detail. Only Teachers are allowed to start this service after authorization taken } \\
\text { from the system or Nodal officer at their VC setup place. NIC has offered this } \\
\text { service using NKN on http://virtualclassroom.nic.in/ }\end{array}$ \\
\hline $\begin{array}{l}\text { Teacher } \\
\& \text { Student }\end{array}$ & Spoken Tutorials & $\begin{array}{l}\text { Click event on Spoken Tutorial will generate the list of Institutes connected } \\
\text { to NKN and offering this Service i.e. Institutes who provides spoken tutorial } \\
\text { on various topics. spoken-tutorial.org is one of the services offered by IITB } \\
\text { and is available for use. }\end{array}$ \\
\hline $\begin{array}{l}\text { Teacher } \\
\& \text { Student }\end{array}$ & Applications on cloud & $\begin{array}{l}\text { Click event on this Menu will generate the list of all the open source } \\
\text { applications available on cloud for use of their choice. Scilab [19] is one of } \\
\text { the examples available on cloud.scilab.in for practice and use. }\end{array}$ \\
\hline
\end{tabular}




\begin{tabular}{|c|c|c|}
\hline $\begin{array}{l}\text { Teacher \& } \\
\text { Nodal officer }\end{array}$ & Remote Lab Access & $\begin{array}{l}\text { Click event on this Menu will generate the list of the connected lab at } \\
\text { different geographic location and its availability for its remote use. Remote } \\
\text { laboratory will use NKN to remotely conduct real (as opposed to virtual) } \\
\text { experiments, at the physical location of the operating technology; It will allow } \\
\text { the scientist and researchers to utilize technology from a separate geographical } \\
\text { location. Remote Physics Experiment at ESRF (Experimental Synchrotron } \\
\text { Research Facility), Grenoble, France on NKN is one example. }\end{array}$ \\
\hline $\begin{array}{l}\text { Teacher } \\
\& \text { Student }\end{array}$ & NPTEL & $\begin{array}{l}\text { Click event on this Menu will simply connect to NPTEL [15] on NKN that } \\
\text { Provides E-learning through online Web and Video courses in Engineering, } \\
\text { Science and humanities streams. }\end{array}$ \\
\hline $\begin{array}{l}\text { Teacher } \\
\& \text { Nodal } \\
\text { officer }\end{array}$ & Virtual Lab Classes & $\begin{array}{l}\text { Click event on this Menu will list the offered lab classes with their details. } \\
\text { Students can watch and interact in live demonstration of the lab but they } \\
\text { cannot control the lab equipments like remote lab. Use policy is same as of } \\
\text { Virtual Class Room. }\end{array}$ \\
\hline $\begin{array}{l}\text { Teacher } \\
\& \text { Student }\end{array}$ & $\begin{array}{l}\text { Feedback to Nodal } \\
\text { officer }\end{array}$ & $\begin{array}{l}\text { Using this button Teachers and students can submit their feedback to Nodal } \\
\text { officer regarding services request, its usage or any other queries. Nodal } \\
\text { officer can forward same to NIC, NKN and other concerned Institutes for } \\
\text { request of services, integration and implementation. }\end{array}$ \\
\hline Nodal officer & Notice \& Event & $\begin{array}{l}\text { Nodal officer can update any News, Notice \& Event send to participating } \\
\text { Institute on the Interface using this tool. }\end{array}$ \\
\hline Nodal officer & Live Webcast & $\begin{array}{l}\text { This tool will scroll the list of live webcasting currently running in various } \\
\text { Institutions. Nodal officer can update the list receives from various NKN } \\
\text { portals. }\end{array}$ \\
\hline Nodal officer & $\begin{array}{l}\text { Products \& Services } \\
\text { offered }\end{array}$ & $\begin{array}{l}\text { This interface will give the details of products and services launched by } \\
\text { various Institutes, NKN, Research organization and NIC. Nodal officer will } \\
\text { give detail of this information on web application framework. }\end{array}$ \\
\hline
\end{tabular}

\section{PROPOSED IT SECURITY FRAMEWORK}

The IT infrastructure comprising both Network and Automation Solution or set of applications which needs to be secured and there should be well designed security framework that will ensure the availability, integrity, and confidentiality of information infrastructure.

A very nice quote by Alan Cox suggest that Poor Security can be worse than no security

"There is a ton of evidence both in computing and outside of it which shows that poor security can be very much worse than no security at all. In particular stuff which makes users think they are secure but is worthless and very dangerous indeed.“

Security threats External and Internal Risk which are identified for an IT infrastructure are given in table1.

Today many organizations including Institutes where security for Information Infrastructure is basically having a firewall and updating the antivirus software regularly, the security model of the IT needs to have strategic policies, security services, relevant technologies, best practices, guidelines, audit and other standards.
Table1. External Security threats and Internal Risks

\begin{tabular}{|cl|l|}
\hline \multicolumn{2}{|c|}{ External Threats } & \multicolumn{1}{c|}{ Internal Risks } \\
\hline $\begin{array}{l}\text { Viruses, worm, Trojan } \\
\text { horse }\end{array}$ & 1. USB Flash Drives \\
\hline 2. & $\begin{array}{l}\text { Distributed denial-of- } \\
\text { service (DDoS) }\end{array}$ & 2. Laptops \\
\hline 3. & Eavesdropping attacks & 3. P2P \\
\hline 4. & Collateral damage & 4. Web Mail \\
\hline 5. & $\begin{array}{l}\text { Unauthorized access } \\
\text { attacks }\end{array}$ & 5. Wi-Fi \\
\hline 6. & $\begin{array}{l}\text { Unauthorized use of } \\
\text { resources and information }\end{array}$ & 6. Smart Phones \\
\hline 7. & Spoofing & $\begin{array}{l}\text { 7. Collaboration Tools } \\
\text { \& Hosted Software }\end{array}$ \\
\hline 8. & Application-specific hacks \\
e.g. SQL injection & 8. Social Networks \\
\hline 9. & Phishing attacks & $\begin{array}{l}\text { 9. Unauthorized } \\
\text { Software Updates }\end{array}$ \\
\hline
\end{tabular}


Four levels (Administrative level, workflow level, information level, and technical level) of security model are proposed and are shown below in the figure6 and related security services are given in table 2 .

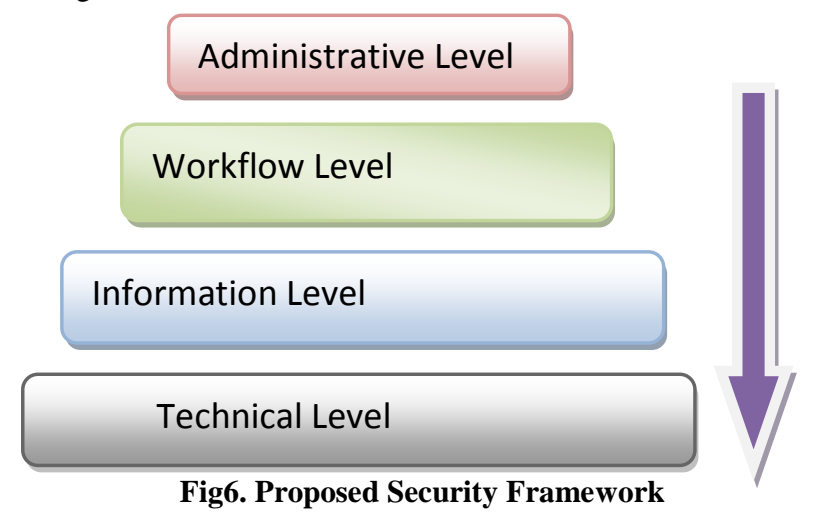

Table2. Security Level \& its related Services

\begin{tabular}{|c|l|}
\hline $\begin{array}{l}\text { Proposed Security } \\
\text { Level }\end{array}$ & Related Security Services \\
\hline Administrative Level & $\begin{array}{l}\text { Administration, Identification of } \\
\text { Problems, Proper Audit, Decision } \\
\text { making under uncertainty, Disaster } \\
\text { Management, IT-security strategies and } \\
\text { formation of policies. }\end{array}$ \\
\hline Workflow level & $\begin{array}{l}\text { Work Flow Level must work towards } \\
\text { Integration of standardized security } \\
\text { framework, applications, protocols and } \\
\text { technologies. }\end{array}$ \\
\hline Information Level & $\begin{array}{l}\text { This level must provide services like } \\
\text { Authentication, Authorization, User } \\
\text { Rights, Access Control, Back-Up \& } \\
\text { Recovery. }\end{array}$ \\
\hline Technical Level & $\begin{array}{l}\text { At the lowest layer following security } \\
\text { [16] needs to be implemented. } \\
\text { Physical Security: This limits physical } \\
\text { access of areas and control rooms to } \\
\text { authorized personnel. } \\
\text { Network Security: - Firewalls with } \\
\text { IPS/IDS, and other QoS policies. } \\
\text { Computer Hardening: - Removal of } \\
\text { unused applications protocols \& } \\
\text { services. } \\
\text { Application Security:- Authentication } \\
\text { \& Authorization of Application usage. } \\
\text { Device Hardening:- Migration and } \\
\text { restrictive access }\end{array}$ \\
\hline
\end{tabular}

\section{CONCLUSION}

In this paper three frameworks are proposed for the best use of NKN services including Network, Application and Security. This paper is written with the objective to help the connected institutes at edge to deploy their Network who have not. Institutes who have their well designed network architecture for them there is need to work for implementation of Application and Security. All the stakeholders of NKN including Institutes, NIC, Research Organizations, and Universities have to work together for implementation and integration of $\mathrm{NKN}$ services and bringing to one user friendly
\& interactive web interface for its better utilization as proposed in this paper.

\section{REFERENCES}

[1] National Knowledge Network - Connecting Knowledge Institutions, http://www.nkn.in/

[2] NKN Design and Architecture: http://www.nkn.in/designarchitecture.php (Accessed on 16th October, 2013)

[3] National Knowledge Commission: http://knowledgecommission.gov.in/

[4] RailTel Corporation of India Ltd http://www.railtelindia.com/index.php?option=com_cont ent\&view $=$ article $\& i d=187 \&$ Itemid $=216 \quad$ (Accessed on 10th Oct, 2013)

[5] NKN Services: GARUDA - NKN PARTNERS MEET 15th July, 2011 National Knowledge Network report page 12 by Shri R.S. Mani, Sr. Technical Director, NIC.

[6] NKN Products and Services: - Launched on the occasion of 2nd NKN Annual workshop, "Enhancing Research Collaboration through NKN" , 17th-19th Oct, 2013 at IISc Bangalore.

[7] NKN, Brochure of First NKN Annual Workshop National Knowledge Network, "The e-Infrastructure of India" (Accessed on December 20th January, 2013)

[8] National Knowledge Network - Second Annual Workshop Presentation "Enhancing Research Collaborations through NKN" IISc Bangalore NKN Workshop, October 2013.

[9] BARC : Bhabha Atomic Research Centre India: http://barc.gov.in/

[10] Garuda : the unique platform for Innovative research collaboration, by Subrata Chattopadhyay CDAC , Bangalore at IISc Bangalore NKN Workshop, October 2013.

[11] TEIN (Trans-Eurasia Information Network) Linkage to NKN by ByungKyu Kim, Ph.D.Executive Officer TEIN* Cooperation Center- Connecting Europe and Asia's Research and Education Communities, IISc Bangalore NKN Workshop, October 2013.

[12] GLOBAL RING NETWORK FOR ADVANCED APPLICATIONS http://www.gloriad.org/gloriaddrupal/ DEVELOPMENT:

[13] Presentation on "The India-Europe cooperation on eInfrastructures, EU-IndiaGrid \& EU-IndiaGrid2 Projects", by Alberto Masoni,in First NKN Annual WORKSHOP http://nkn.in/nkn.../slides/.../EUIndia\%20Grid\%20by\%20A.\%20Masoni.pdf

[14] Remote Physics Experiment at ESRF (Experimental Synchrotron Research Facility), Grenoble, France on NKN, http://www.nkn.in/virtual_lab.php

[15] NPTEL(National Programme on Technology Enhanced Learning), http://nptel.iitm.ac.in/

[16] White Paper on Securing Manufacturing Computing and Controller Assets, Rockwell Automation, CISCO. 